\title{
Renal damage from industrial arsine poisoning
}

\author{
P. R. ULDALL, H. A. KHAN, J. E. ENNIS, R. I. MCCALLUM, and \\ T. A. GRIMSON \\ Newcastle upon Tyne Hospitals and the Durham Group of Hospitals
}

\begin{abstract}
Uldall, P. R., Khan, H. A., Ennis, J. E., McCallum, R. I., and Grimson, T. A. (1970). Brit. J. industr. Med., 27, 372-377. Renal damage from industrial arsine poisoning. An incident is reported in which three men were accidentally poisoned by arsine $\left(\mathrm{A}_{\mathbf{s}} \mathbf{H}_{3}\right)$ in an industrial chemical plant. Two mildly affected individuals recovered quickly-without treatment but the third, who was severely poisoned, developed oliguric renal failure. Though this patient recovered after repeated peritoneal dialysis he was left with a legacy of chronic renal insufficiency and hypertension. This severe case drew attention to a previous incident in the same factory involving three other men, the cause of which had not hitherto been suspected.

The previous reports of arsine-induced renal failure treated by dialysis have been reviewed and certain common features are apparent. Dangerous uraemia may persist long after the onset of the diuretic phase. Dialysis provides a high chance for recovery in what was previously a universally fatal condition, but permanent renal interstitial damage is a likely sequel. There are strong reasons for the prompt use of exchange transfusion in the severely affected patient with oliguria.

Mild arsine poisoning unaccompanied by oliguria may remain unrecognized and should therefore be considered in the differential diagnosis of any patient presenting with haematuria or jaundice, particularly if his occupation brings him in contact with acids and metals.
\end{abstract}

Arsine poisoning, manifested by acute haemolysis and a variable degree of hepatic and renal damage, is an industrial hazard which has long been recognized (Hunter, 1957). The global distribution of reported incidents and the extremely diverse nature of industrial processes in which exposures have occurred, together with the ever increasing development of new industrial processes, combine to increase the likelihood of more accidents in the future, even though the typical conditions of their occurrence and methods of prevention are well known.

The mortality rate of 20 to $30 \%$ in various reported series is explicable in nearly every case on the basis of renal failure or its complications and, until recent years, the mortality approached $100 \%$ in patients presenting with oliguria (Locket, Grieve, and Phillips, 1952). In recent years there have been reports of recovery from arsine-induced renal failure treated by dialysis with or without exchange transfusion (Gaultier, Tanret, and Reymond, 1949; Ullrich, 1958; Neuwirtová, Chytil, Valek, Daum, and Valach, 1961 ; Dérot, Legrain, Jacobs, Prunier, and Hazebroucq, 1963; Anthonisen, Nielsen, Pedersen, and Raaschou, 1968; Coles, Davies, Daley, and Mallick, 1969; Teitelbaum and Kier, 1969; Hocken and Bradshaw, 1970).

We present here the case histories of three men simultaneously affected in an industrial arsine poisoning incident. Two mildly affected individuals recovered spontaneously with only transient renal impairment. The other victim was severely affected but recovered after a prolonged period of uraemia treated by repeated dialysis. This case, in common with others reported in the literature, demonstrated certain special features of arsine-induced renal damage which may serve as a guide to the management of patients involved in future incidents. 


\section{The background of the incident}

The three men worked regularly on the production of purified zinc sulphate liquor. The raw materials included crude liquors from three sources and solid zinc residues from miscellaneous sources such as smelting and galvanizing. One stage of the process involves the treatment of several thousand gallons of crude liquors with additional zinc residues and acid in a steam-heated wooden vat in the mouth of which is a wire cage. A charge of metallic zinc dust is periodically poured from a drum into the cage. A careful study of the sources of liquor processed by these men during the work period preceding their illness identified the material likely to be contaminated with arsenic. A sample of this material was found to contain $0.1 \mathrm{~g}$ arsenic per $100 \mathrm{ml}$ in acid solution. The precise way in which the arsine was inhaled is not entirely clear as fume extraction was thought to be efficient and none of the men noticed anything wrong at the time. It seems likely that a very brisk evolution of arsine from the vat opening must have occurred during the tipping of metal from a drum into the vat. This operation necessitates that the workers should stand at the vat opening for a few minutes. The two mildly affected individuals were working on this process for about an hour, while the severely affected patient spent about seven hours carrying out the work.

The process had been carried out for about 15 years without any detected poisoning. In February 1968 three other men had been taken ill, two of whom worked together as a shift team, while the third frequently assisted them. One man had been absent from work for 23 days with 'cystitis and haematuria', a second for 19 days with 'haematuria' and a third had had mild 'jaundice' but continued working. This incident was noted by the company who sought medical advice, but at the time arsine poisoning was not suspected. The liquor which these men had processed came from the same source as that in the second and more serious incident. As a sample of this material was still available its arsenic content was checked and found to be $0.023 \mathrm{~g} / 100 \mathrm{ml}$. Samples of hair and nail clippings from three mildly affected individuals were obtained in June 1968 and were all found to contain arsenic in significant amounts (Table 1).

\section{Reports of present cases}

Severely affected patient

Case 1 J.B., a 50-year-old man, was admitted to the General Hospital, Chester-le-Street, on March 28, 1968. He had left work at $10.00 \mathrm{pm}$ three days previously feeling nauseated, lethargic and anorexic. Within hours he became hot and then cold with rigors followed by severe abdominal pain and backache. Cramping abdominal pain continued during the night and was aggravated by drinking water. By the morning his skin
TABLE 1

Arsenic in Finger Nails and Hair of Three Men EMployed on the Zinc Purification

Process

\begin{tabular}{c|c|c}
\hline \multirow{3}{*}{ Patient } & \multicolumn{2}{|c}{$\begin{array}{c}\text { Concentration of arsenic } \\
(\text { ppm) }\end{array}$} \\
\cline { 2 - 3 } & $\begin{array}{c}\text { Microchemical } \\
\text { nails }\end{array}$ & $\begin{array}{c}\text { Neutron } \\
\text { activation } \\
\text { hair }\end{array}$ \\
\hline 1 & $1 \cdot 6$ & 2 \\
2 & $5 \cdot 8$ & $3-4$ \\
3 & $8 \cdot 2$ & 8 \\
Control & - & 1 \\
\hline
\end{tabular}

${ }^{1}$ Nuffield Department of Industrial Health.

${ }^{2}$ Mr. P. J. Hewitt, Radiation Protection Officer, University of Bradford.

was pigmented and he was passing dark red urine and dark watery motions accompanied by mucus. His wife commented that his hair, which had previously been dark, had become grey overnight. From then until the time of admission to hospital he was alternately restless, lethargic and confused. He became increasingly dyspnoeic.

$\mathrm{He}$ had a previous history of two short attacks of frequency and dysuria in 1965 . He was normotensive at that time, his urine showing no protein or any abnormality on microscopy. Culture was negative for pyogenic organisms and tubercle bacilli. The blood urea was $41 \mathrm{mg} \%$. No further investigations were undertaken and he had no recurrence of symptoms until the present episode.

On admission to hospital the patient looked very ill and was mildly confused and disorientated. He was moderately dyspnoeic. He had a yellowish-brown pigmentation of the skin and conjunctivae, and the mucous membranes were pale. The liver was three fingerbreadths enlarged and acutely tender. There was also a generalized abdominal tenderness. The temperature was $98^{\circ} \mathrm{F}$ $\left(36.7^{\circ} \mathrm{C}\right)$, pulse $80 /$ minute regular and blood pressure $150 / 90 \mathrm{~mm} \mathrm{Hg}$. The chest was clear and neurological examination negative.

Investigations The urine contained protein ++ . Microscopy showed numerous red cells as well as red cell casts, granular casts, and renal epithelial cells. Urine spectroscopy showed a heavy concentration of oxyhaemoglobin and some methaemoglobin.

$\mathrm{Hb} 43 \%, 6.1 \mathrm{~g} / 100 \mathrm{ml}$; PCV $18 \%$; MCHC $34 \%$; ESR $92 \mathrm{~mm} /$ hour; WBC $14300 / \mathrm{mm}^{3}$, polymorphs $83 \%$. The red cells showed moderate anisocytosis, some punctate basophilia and polychromasia. The neutrophils showed a shift to the left.

Serum electrolytes: $\mathrm{Na} 139 \mathrm{mEq} / \mathrm{litre}, \mathrm{K} 6.8 \mathrm{mEq} / \mathrm{litre}$, Cl $96 \mathrm{mEq} / \mathrm{litre}, \mathrm{CO}_{2} 22 \cdot 2 \mathrm{mEq} / \mathrm{litre}$. Blood urea 416 $\mathrm{mg} \%$. Serum bilirubin: total $4.7 \mathrm{mg} \%$, direct $1.8 \mathrm{mg} \%$, indirect $2.9 \mathrm{mg} \%$. The serum contained methaemoglobin (Schumm's test). Alkaline phosphatase 9.0 KA units. Serum proteins: total $7.0 \mathrm{~g} \%$, albumin $4.2 \mathrm{~g} \%$, globulin $2.8 \mathrm{~g} \%$. SGOT 260 Sigma Frankel units. 
An occult blood test of the stools was strongly positive. A chest radiograph was normal.

The urine volume in the first 24 hours was $400 \mathrm{ml}$.

Peritoneal dialysis was started on the evening of admission and the patient received a transfusion of 2 units of packed cells. A 1.5-litre sample of dialysis fluid, taken shortly after starting dialysis, contained arsenic in a concentration of $20 \mathrm{mg} /$ litre. A 24-hour urine sample the day after admission contained $220 \mathrm{mg} /$ litre of arsenic in a total volume of $410 \mathrm{ml}$. With the first dialysis, consisting of 45 cycles, the blood urea came down to 248 $\mathrm{mg} / 100 \mathrm{ml}$ and the haemoglobin rose to $7 \cdot 7 \mathrm{~g} / 100 \mathrm{ml}$. On the 8th day after the poisoning the blood urea had risen to $312 \mathrm{mg} / 100 \mathrm{ml}$ and the patient's general condition had deteriorated. Another peritoneal dialysis, complicated by a promptly treated bacterial peritonitis, lowered the blood urea to $78 \mathrm{mg} / 100 \mathrm{ml}$. On the 10 th day intramuscular injections of BAL, $50 \mathrm{mg}$ every six hours, were started and continued for 48 hours. On the 11th day the daily urine volume exceeded $1300 \mathrm{ml}$ but the creatinine clearance was less than $2 \mathrm{ml} /$ minute. The patient received another two units of packed cells on the 16th day. The blood urea continued to rise to $348 \mathrm{mg} / 100 \mathrm{ml}$ by the 23rd day when a third peritoneal dialysis was started which lowered the blood urea to $172 \mathrm{mg} / 100 \mathrm{ml}$. During the dialysis he received 3 pints of whole blood. On the 26th day a percutaneous needle biopsy of the right kidney was performed. A photomicrograph is shown (Fig. 1).

Renal biopsy findings A specimen was obtained of cortical tissue, $1.2 \mathrm{~cm}$ in length, containing 12 glomeruli. One glomerulus was completely hyalinized with a degenerated nephron. The rest of the glomeruli and the Bowman's capsules appeared normal except that the capillary tufts appeared somewhat bloodless. The con- voluted tubules appeared very dilated and the epithelial lining in some was still necrotic. In others the tubular cell layer was either very flat or apparently regenerating. The lumens contained shed epithelium, a few leucocytes, and granular or golden brown pigment casts. The connecting tubules contained eosinophilic amorphous casts. The interstitium showed oedema, early fibrosis and foci of round cells. The appearance was of a severe tubular and interstitial lesion with partial regeneration.

Subsequent progress Following the renal biopsy the patient remained anaemic and uraemic; despite a haemoglobin of $9.5 \mathrm{~g} / 100 \mathrm{ml}$ before the biopsy the reticulocytes were less than $1 \%$. On the 29th day a needle aspiration of bone marrow was obtained. The specimen showed a cellular marrow with normal stainable iron content. The picture was of normoblastic maturation with some arrest at a late polychromatic stage.

The patient's blood urea rose to $260 \mathrm{mg} / 100 \mathrm{ml}$ on the 29th day and thereafter began gradually to fall spontaneously. His condition slowly improved so that on the 66th day he was ambulant and fit to be discharged home. Investigations just before discharge showed haemoglobin of $10.5 \mathrm{~g} / 100 \mathrm{ml}$, blood urea $90 \mathrm{mg} / 100 \mathrm{ml}$ and creatinine clearance $22 \mathrm{ml} / \mathrm{minute}$. The urine still contained a trace of protein $(200 \mathrm{mg} / 24$ hours). Liver function tests were normal. The graphs (Fig. 2) record his progress during his stay in hospital.

Approximately one year after the episode the patient was clinically well apart from mild hypertension (BP $170 / 110 \mathrm{~mm} \mathrm{Hg}$ ) but he still had significant impairment of renal function. Intravenous pyelography showed symmetrical shrinking of the kidneys, the respective lengths being right $11.5 \mathrm{~cm}$ and left $11.8 \mathrm{~cm}$.

The maximum urinary osmolality after 18 hours of

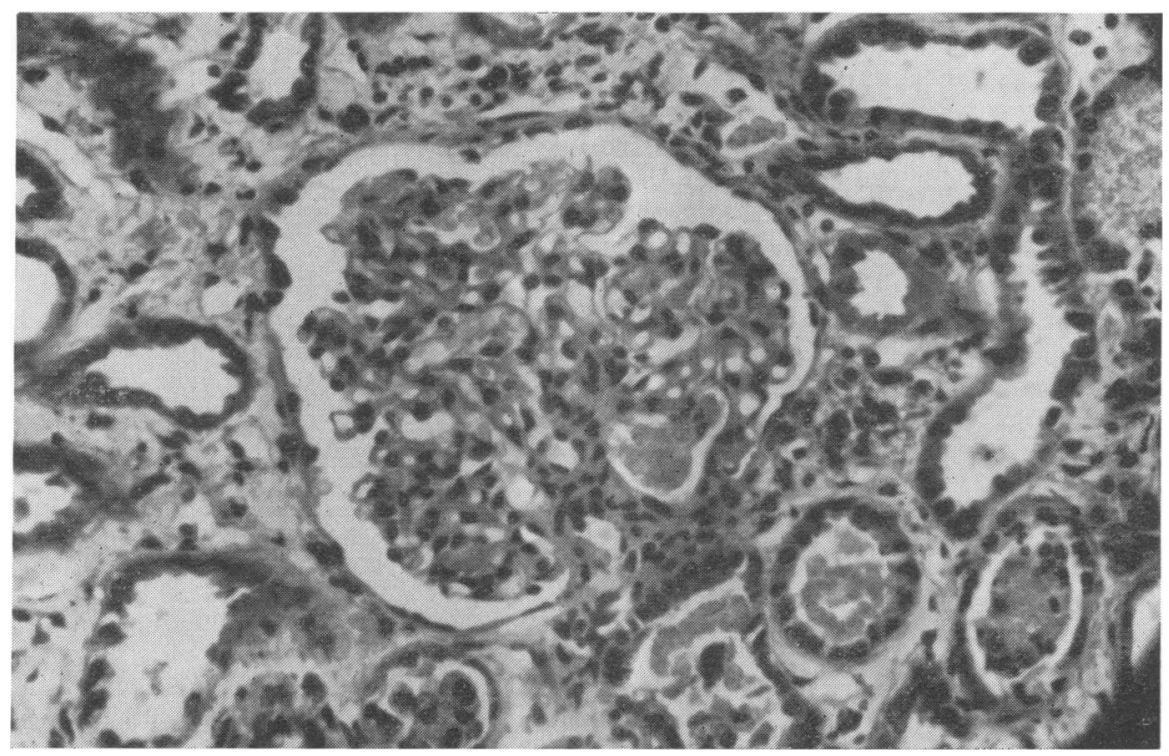

FIG. 1. Case 1. Photomicrograph of renal biopsy. $\times 130$. 


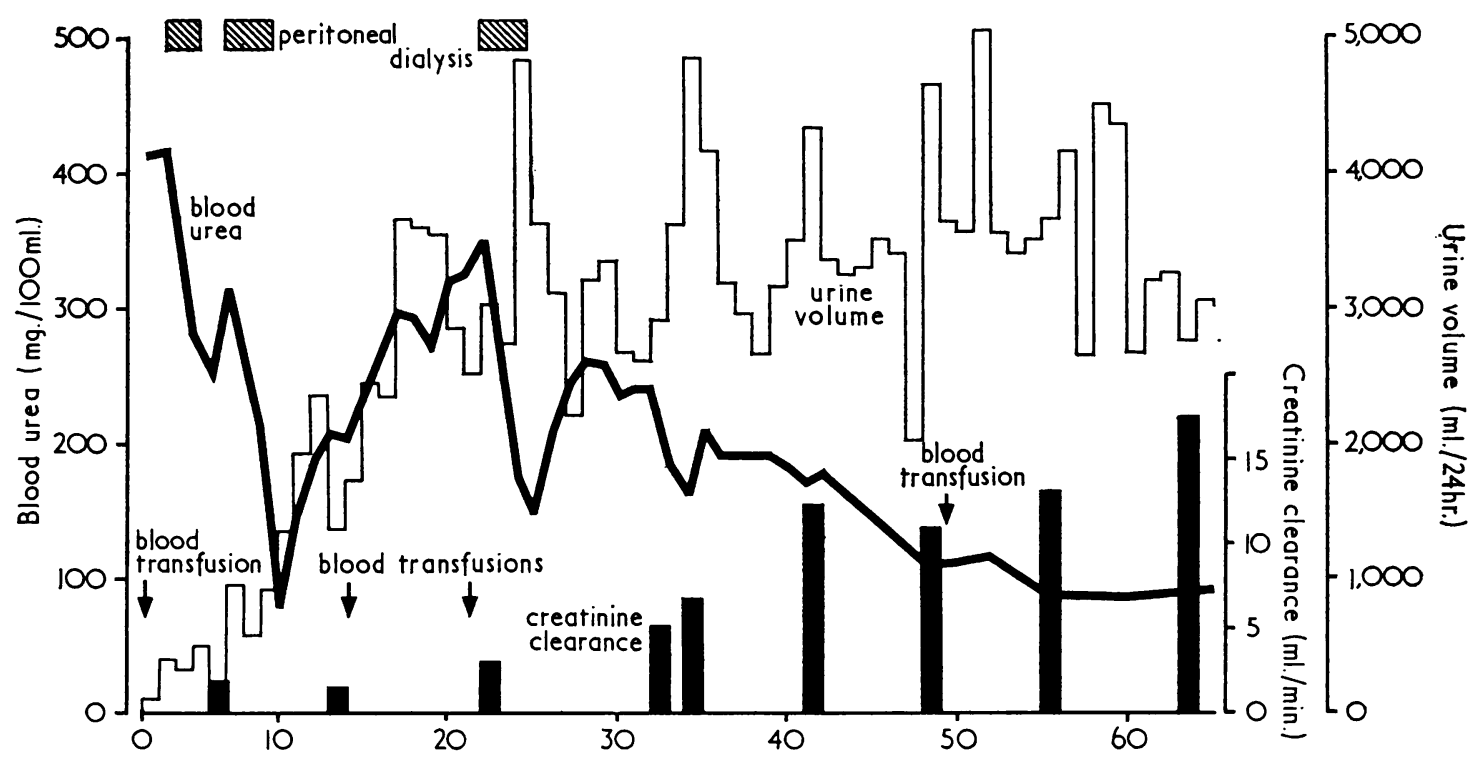

FIG. 2. Case 1. Progress during hospital stay.

fluid deprivation was $448 \mathrm{mOsm} / \mathrm{kg}$ (normal $=>800$ $\mathrm{mOsm} / \mathrm{kg}$ ). The blood urea was $62 \mathrm{mg} / 100 \mathrm{ml}$, serum creatinine $2.2 \mathrm{mg} / 100 \mathrm{ml}$, creatinine clearance $42 \mathrm{ml} /$ minute and urine protein $0.7 \mathrm{~g} / 24$ hours. The urinary ammonium was $13.8 \mathrm{mEq} / 24$ hours and paper chromatography showed a slight generalized increase in amino acid excretion.

The patient's hair has returned to its original colour but the hypertension has increased.

\section{Mildly affected patients}

Case 2 J.A., aged 63, was admitted to hospital on 30 March with the history that three days previously he had returned home from work in the morning and passed dark red urine. He also had diffuse upper abdominal discomfort. The next day he was anorexic, dyspnoeic on exertion, somewhat nauseated, and disinclined to smoke cigarettes.

He had a previous history of obstructive jaundice followed by cholecystectomy in 1964.

On examination he appeared well. He was slightly pale but had no detectable jaundice. The liver was three fingerbreadths enlarged below the right subcostal margin and slightly tender.

The urine was dark brown in colour and contained protein in excess of $1 \mathrm{~g} / 100 \mathrm{ml}$. Microscopy revealed numerous red cells, granular casts, and red cell casts.

Investigations $\mathrm{Hb} 8.9 \mathrm{~g} / 100 \mathrm{ml}$; PCV $27 \%$; MCHC $33 \%$; ESR $55 \mathrm{~mm} /$ hour; WBC $12700 / \mathrm{mm}^{3}$, normal differential.

Blood urea $61 \mathrm{mg} \%$. Electrolytes normal. Serum creatinine $1.0 \mathrm{mg} \%$. Serum bilirubin: total $1.7 \mathrm{mg} \%$, direct $0.4 \mathrm{mg} \%$, indirect $1.3 \mathrm{mg} \%$. Alkaline phosphatase $7 \cdot 1 \mathrm{KA}$ units. Plasma proteins: total $6.2 \mathrm{~g} \%$, albumin $3.4 \mathrm{~g} \%$, globulin $2.8 \mathrm{~g} \%$. SGOT 15 Sigma Frankel units.
A chest radiograph showed slight changes of pneumoconiosis.

The ECG was normal.

The urine contained arsenic, $130 \mathrm{mg} /$ litre.

He was given no specific treatment. Within two days the urine was macroscopically clear and the blood urea was $41 \mathrm{mg} / 100 \mathrm{ml}$. Three days after admission the 24-hour creatinine clearance was $137 \mathrm{ml} /$ minute. Ten days after admission the serum creatinine had risen to $1.4 \mathrm{mg} / 100 \mathrm{ml}$ and creatinine clearance had fallen to $73 \mathrm{ml} /$ minute. Urine protein was $0 \cdot 14 \mathrm{~g} / 24$ hours.

One month after admission the patient was well. Urine microscopy was negative. Creatinine clearance $90 \mathrm{ml} /$ minute. Urine protein $0.28 \mathrm{~g} / 24$ hours. Maximum urine osmolality after 18 hours fluid deprivation 636 $\mathrm{mOsm} / \mathrm{kg}$.

Two months after admission urine microscopy was negative. Creatinine clearance $141 \mathrm{ml} / \mathrm{minute}$. Serum creatinine $1.1 \mathrm{mg} \%$. Urine protein $0.3 \mathrm{~g} / 24$ hours. Maximum urine osmolality after 18 hours fluid deprivation $746 \mathrm{mOsm} / \mathrm{kg}$.

Thus, apart from minimal proteinuria, he had recovered normal renal function.

Case 3 F.A., aged 26, was admitted to hospital on 30 March 1968 with a complaint of jaundice and headache. Four days earlier he had returned from work complaining of upper abdominal pain and of passing dark red urine. For the next two days he was anorexic and nauseated and vomited repeatedly. He developed a tinge of jaundice. There was no previous history of ill health. Physical examination on admission was completely negative apart from mild hypertension - blood pressure $145 / 95 \mathrm{~mm} \mathrm{Hg}$. The jaundice noticed by his own doctor had disappeared.

The urine was normal in colour but microscopy 
revealed moderate numbers of red cells and red cell casts. There was a trace of protein.

Investigations $\mathrm{Hb} 12.0 \mathrm{~g} / 100 \mathrm{ml}$; PCV $36 \%$; MCHC $33 \%$; ESR $38 \mathrm{~mm} /$ hour; WBC $10200 / \mathrm{mm}^{3}$, normal differential.

Blood urea $25 \mathrm{mg} \%$. Serum bilirubin: total $1.3 \mathrm{mg} \%$, direct $0.4 \mathrm{mg} \%$, indirect $0.9 \mathrm{mg} \%$. Alkaline phosphatase 8.2 KA units. Plasma proteins: total $6.0 \mathrm{~g} \%$, albumin $3.5 \mathrm{~g} \%$, globulin $2.5 \mathrm{~g} \%$. SGOT 25 Sigma Frankel units.

A chest radiograph showed no abnormality.

The ECG was normal.

The urine contained arsenic, $175 \mathrm{mg} /$ litre.

Nine days after admission urine microscopy was negative. Creatinine clearance $77.5 \mathrm{ml} / \mathrm{minute}$. Urine protein $0.91 \mathrm{~g} / 24$ hours.

One month after admission the blood pressure was $120 / 80 \mathrm{~mm} \mathrm{Hg}$; Hb $17.7 \mathrm{~g} / 100 \mathrm{ml}$; ESR $1 \mathrm{~mm} /$ hour; WBC $11 \mathrm{900} / \mathrm{mm}^{3}$. Urine microscopy was negative. Creatinine clearance $127 \mathrm{ml} /$ minute. Urine protein 0.29 g/24 hours. Maximum urine osmolality after 18 hours fluid deprivation $614 \mathrm{mOsm} / \mathrm{kg}$.

Two months after admission urine microscopy was negative. Creatinine clearance $147 \mathrm{ml} / \mathrm{minute}$. Urine protein $0.85 \mathrm{~g} / 24$ hours. Maximum urine osmolality $820 \mathrm{mOsm} / \mathrm{kg}$.

Thus, apart from mild persistent proteinuria, there was no evidence of impaired renal function.

\section{Discussion}

These patients were poisoned by arsine in the typical situation in which such accidents occur, namely in a chemical or metallurgical industry as the result of the action of acid on material containing arsenic.

We have found reports of 15 other patients treated by dialysis for acute renal failure from arsine intoxication (Table 2). Of these 15, 11 have survived and 4 have died of renal failure or its complications (giving a mortality rate of $27 \%$ ). Clearly, dialysis, either peritoneal or haemodialysis, is the factor which has been responsible for saving 11 out of 15 lives in a condition which previously carried a mortality of $100 \%$. Two of the most severely affected patients who survived, those of Muehrcke and Pirani (1968) and Teitelbaum and Kier (1969), were also treated with exchange transfusion to remove the arsenic-haemoglobin complex. The authors stress the importance of this aspect of management, and their accounts certainly suggest that the procedure was beneficial. This method receives theoretical support from the work of Graham, Crawford, and Marrian (1946), who showed that, in experimental animals poisoned with arsine, a large proportion of the fixed arsenic in the blood was in a non-dialysable form.

Our severely affected patient (case 1) illustrates some of the features noted in other patients who have survived after arsine-induced renal failure. Firstly, in common with five other survivors out of a total of nine in whom late renal function has been documented, he shows moderately severe renal insufficiency as a legacy of his exposure. Thus the statements by Steel and Feltham (1950) and McKinstry and Hickes (1957), that complete recovery is the rule in survivors, does not hold true in the severely affected patients requiring dialysis. Rather it would seem that there is a considerable likelihood of long-standing renal impairment if renal damage is severe enough to require dialytic therapy. The argument for early exchange transfusion in reducing renal damage and long-term renal insufficiency seems very strong. It is possible that by its use we might have avoided or decreased the chronic renal insufficiency in our patient. Secondly, our patient, in common with four out of nine patients on whom information is available, continued with severe uraemia long after the onset of a profuse diuresis. This may be explained partly by the intense and prolonged catabolic state that

TABLE 2

A Summary of the Outcome of Previous Patients Treated for Arsine-induced Renal Failure BY Dialysis

\begin{tabular}{|c|c|c|c|c|}
\hline Author & $\begin{array}{c}\text { No. of } \\
\text { patients }\end{array}$ & Method of treatment & Survivors & Deaths \\
\hline $\begin{array}{l}\text { Gaultier et al. (1949) } \\
\text { Ullrich (1958) } \\
\text { Neuwirtová et al. (1961) } \\
\text { Dérot et al. (1963) } \\
\text { Ikegami et al. (1967) } \\
\text { Muehrcke and Pirani (1968) } \\
\text { Coles et al. (1969) } \\
\text { Teitelbaum and Kier (1969) } \\
\text { Anthonisen et al. (1968) } \\
\text { Hocken and Bradshaw (1970) }\end{array}$ & $\begin{array}{l}1 \\
1 \\
3 \\
4 \\
1 \\
1 \\
1 \\
1 \\
1 \\
1\end{array}$ & $\begin{array}{l}\text { Peritoneal dialysis } \\
\text { Peritoneal dialysis } \\
\text { Haemodialysis } \\
\text { Peritoneal and haemodialysis } \\
\text { Peritoneal and haemodialysis } \\
\text { Exchange transfusion and haemodialysis } \\
\text { Peritoneal dialysis } \\
\text { Exchange transfusion and haemodialysis } \\
\text { Haemodialysis } \\
\text { Peritoneal dialysis }\end{array}$ & $\begin{array}{l}1 \\
1 \\
1 \\
3 \\
1 \\
1 \\
1 \\
1 \\
1\end{array}$ & $\begin{array}{l}- \\
2 \\
1 \\
- \\
- \\
-\end{array}$ \\
\hline Total & 15 & & 11 & 4 \\
\hline
\end{tabular}


follows arsine intoxication (Teitelbaum and Kier, 1969). The practical point is that dialysis may be required long after the onset of the diuretic phase. Thirdly, our patient's renal biopsy carried out 26 days after intoxication showed the characteristic interstitial damage described by many other authors, the most detailed histological description being that of Muehrcke and Pirani (1968). Finally, a particular feature of our patient which has not been described hitherto is the late onset of hypertension (BP $170 / 110 \mathrm{~mm} \mathrm{Hg}$ one year after the incident) and this may justifiably be attributed to the renal damage.

The use of BAL was very late in our patient because of delay in diagnosis and from what we know it was almost certainly of no benefit. Most authorities consider it to be of very doubtful value even if given within hours of the exposure. The only substance known experimentally to be of any value is 2-3 dimercaptopropyl ethyl ether (Kensler, Abels, and Rhoads, 1946) but this is considered to be too toxic for clinical use.

The two mildly affected cases we have described caused no anxiety or difficulty in management but they did demonstrate renal tubular damage lasting for several weeks. That such an illness could easily go unrecognized if not accompanied simultaneously by a more severely affected case was clearly shown by the other three men whose 'haematuria' and 'jaundice' were explained only after the discovery of arsenic in the hair and nails four months later. One can only speculate on the long-term danger to renal function that could result from repeated mild exposures such as these. A detailed examination of the renal function of all the workers in such a factory would be reassuring if negative and might prove to be an important contribution to future safety precautions if an unexpectedly high incidence of impaired urine concentrating ability were demonstrated.

Some comment should be made on the observation by the wife of case 1 , corroborated by others, that his hair turned white overnight after the exposure to arsine. Although this sounds somewhat improbable, the same observation that the hair turned acutely white was made by Anthonisen and his colleagues (1968) in their severely affected patient. There is perhaps an explanation for this in the work of
Lander, Hodge, and Crisp (1965), who found high levels of arsenic in the hair and finger and toe nails in 25 cases of acute arsenical poisoning within a few hours of exposure. Washing the tissues concerned did not alter these levels. They considered that the high levels of arsenic found in sweat could provide an explanation for impregnation of the hair and nails.

\section{References}

Anthonisen, P., Nielsen, B., Pedersen, K., and Raaschou, F. (1968). Clinical picture and treatment in arsine poisoning. Acta med. scand., Suppl. 496, 14-22.

Coles, G. A., Davies, H. J., Daley, D., and Mallick, N. P. (1969). Acute intravascular haemolysis and renal failure due to arsine poisoning. Postgrad. med. J., 45, 170-172.

Dérot, M., Legrain, M., Jacobs, C., Prunier, P., and Hazebroucq, G. (1963). Intoxication par l'hydrogène arsénié. Etude des formes rénales à propos d'une intoxication collective (5 cas). J. Urol. Néphrol., 69, 407-433.

Gaultier. M., Tanret, P., and Reymond, J.-C. (1949). Commentaires sur deux cas d'intoxication grave par l'hydrogène arsenié à évolution prolongée. Bull. Soc. méd. Hôp. Paris, 65, 951-959.

Graham, A. F., Crawford, T. B. B., and Marrian, G. F. (1946). The action of arsine on blood. Observations on the nature of the fixed arsenic. Biochem. J., 40, 256-260.

Hocken, A. G., and Bradshaw, G. (1970). Arsine poisoning. Brit. J. industr. Med., 27, 56-60.

Hunter, D. (1957). The Diseases of Occupations, 2nd ed. p. 301. English Universities Press, London.

Ikegami, K., Nakamura, T., and Kanbara, T. (1967). A case of acute renal failure due to arsenuretted hydrogen poisoning undergone a long-term peritoneal dialysis. Jap. J. Urol., 58, 369-380.

Kensler, C. J., Abels, J. C., and Rhoads, C. P. (1946). Arsine poisoning, mode of action and treatment. J. Pharmacol. exp. Ther., 88, 99-108.

Lander, H., Hodge, P. R., and Crisp, C. S. (1965). Arsenic in hair and nails. Its significance in acute arsenical poisoning. J. forens. Med., $12,52-67$.

Locket, S., Grieve, W. S. M., and Phillips, L. (1952). Arsine poisoning. Trans. Ass. industr. med. Offrs, 2, 14-22.

McKinstry, W. J., and Hickes, J. M. (1957). Emergency - arsine poisoning. Arch. industr. Hith, 16, 32-41.

Muehrcke, R. C., and Pirani, C. L. (1968). Arsine-induced anuria. A correlative clinicopathological study with electron microscopic observations. Ann. intern. Med., 68, 853-866.

Neuwirtová, R., Chytil, M., Valek, A., Daum, S., and Valach, V. (1961). Acute renal failure following an occupational intoxication with arsine $\left(\mathrm{As} \mathrm{H}_{3}\right)$ treated by the artificial kidney. Acta med. scand., 170, 535-546.

Steel, M., and Feltham, D. V. G. (1950). Arsine poisoning in industry. Report of a case. Lancet, 1, 108-110.

Teitelbaum, D. T., and Kier, L. C. (1969). Arsine poisoning. Report of five cases in the petroleum industry and a discussion of the indications for exchange transfusion and hemodialysis. Arch. environm. Hlth, 19, 133-143.

Ullrich, G. (1958). Verlauf und Behandlung einer "akuten toxischen Neireninsuffizienz" nach Arsenwasserstoffvergiftung. Wien. klin. Wschr., 70, 538-544.

Received for publication March 12, 1970. 